\title{
Földrajz és nemzetépítés Közép- és Kelet-Közép-Európában Nemzetközi konferencia az ELTE Eötvös József Collegiumban
}

\author{
Geography and nation building in \\ Central and East Central Europe \\ International workshop at the ELTE Eötvös József Collegium
}

\author{
PALACZKI BOTOND
}

\begin{abstract}
PALACZKI Botond: PhD-hallgató, Eötvös Loránd Tudományegyetem, Társadalom- és Gazdaságföldrajzi Tanszék, Budapest; palaczki.botond@gmail.com
\end{abstract}

Botond PALACZKI: PhD student, Eötvös Loránd University, Department of Social and Economic Geography, Budapest; palaczki.botond@gmail.com

Az ELTE Eötvös József Collegiumban 2013. július 11-12-én nemzetközi történeti földrajzi konferenciát rendeztek Földrajz és nemzetépités Közép- és Kelet-Közép-Európában címmel. Győri Róbert (ELTE Társadalom- és Gazdaságföldrajzi Tanszék, Eötvös József Collegium), Gyuris Ferenc (ELTE Regionális Tudományi Tanszék, Eötvös József Collegium) és Steven Jobbitt (California State University, Fullerton, Department of History) 2012-ben mühelykonferencia szervezésébe kezdett, a jelentkezők száma azonban az eredetileg tervezettnél hosszabb, kétnapos lebonyolítást kívánt. A programban szereplő témáknak és kérdéseknek korábban nem szenteltek nemzetközi konferenciát, így az esemény kiváló alkalmat nyújtott arra is, hogy az ezekkel foglalkozó, a hétköznapokban egymástól jelentős földrajzi távolságra élő kutatók összegyüljenek: a résztvevők valóban változatos helyekről érkeztek (Nagy Britannia, Egyesült Államok, Németország, Franciaország, Olaszország), az előadók és szekcióvezetők révén tizenhat intézmény képviseltette magát a konferencia két napján. Összesen hat, egymáshoz szorosan kapcsolódó témába rendeződött a konferencia tizennyolc előadása. A Collegium igazgatójának nyitóbeszéde után elsőként tudományelméleti kérdésekről esett szó, a további szekciókat pedig a tárgykörbe tartozó államok 20. századi életciklusának fejezetei alkották.

Az első szekció a földrajzi tudás, a nemzetépítés és a hatalom kapcsolatrendszeréről, valamint az ennek tanulmányozására felállított elméleti keretről

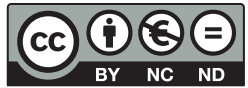


szólt. Az előadások sorát az angolszász és a kontinentális német iskola egy-egy neves képviselője nyitotta, bemutatva a tematikán átívelő problémák elméleti hátterét és azok vizsgálatának alapjait. Charles Withers (University of Edinburgh, Institute of Geography) életművének egyik központi témájára, a felvilágosodástól formálódó tudomány történeti földrajzi vizsgálatára építette előadását, kiemelve az ezekben a kutatásokban lezajlott térbeli fordulatot. Felvázolta a konferencián később is előkerülő gondolatok elméleti alapjait (például az anyagi cselekvők kérdését és a nemzetnek a földrajzi vizsgálat alapegységeként való értelmezését). Peter Meusburger (Universität Heidelberg, Geographisches Institut) a nemzetállamok és a közoktatási rendszerek általa régóta kutatott kapcsolatáról beszélt. Számos példát mutatott a többnyelvű államok iskolarendszereinek nacionalista célok támogatására használt eszközeire, melyek később, a világháborúk idején a politikai ellentétek élesedéséhez vezettek. A bevezető előadások között magas színvonaluk ellenére kevés módszertani vagy elméleti kapcsolat volt. Így kevésbé tűnt koherensnek a szekció, inkább két különböző gondolati ív bevezetőjeként volt értelmezhető.

A második szekcióban a földrajznak a Párizs környéki békeszerződések során tapasztalt felértékelődéséről hallhattunk előadásokat. Az első világháborút követően a döntéshozók legfontosabb támaszává vált a feltörekvő tudományterület, mely kulcsszerepet játszott Európa határainak átrajzolásában is. Az elöadások kiválóan szemléltették a földrajz jelentőségét és népszerűségét, hiszen a tárgyalások során a szemben álló felek hasonló földrajzi érvrendszerrel próbálták álláspontjukat támogatni. Michael Heffernan (University of Nottingham, School of Geography) a kartográfiai és geográfiai dokumentumok szerepének békekonferenciához köthető fellendülését vizsgálta. Az előadásban rámutatott a béketárgyalásoknak két jól elkülönülő, de egymással szoros kapcsolatban álló földrajzára: a tárgyalások „külső” földrajzára, melyet a tudományterület képviselői alakítottak ki az összetett geopolitikai viták kommunikálásával, valamint a konferencia „belső” földrajzára, amely az események különböző párizsi helyszínein alakult ki. Gaëlle Hallair (Goethe-Universität, Frankfurt) a tárgyaló felek gyakran közeli barátságban álló geográfusainak akadémián kívüli szerepéről, a kialakuló ellentmondásokról és vitákról számolt be, kiemelve Emmanuel de Martonne szerepét Közép-Európa új határainak megalkotásában. Krasznai Zoltán (Európai Bizottság, Kutatási és Innovációs Főigazgatóság) a szekció utolsó előadójaként Teleki Pálnak a magyar delegációban betöltött földrajzi szakértői szerepéről beszélt. Utóbbi két előadás a kiemelt földrajztudósok szerepét és érvelésük hasonlóságait különösen szemléletesen mutatta be, ennek köszönhetöen talán a szekció a konferencia egyik legjobbját alkotta.

A földrajz hatalmi szerepének megerősödésével a diszciplína a béketárgyalások alatt és után a különböző revizionista törekvések fontos eszköze volt, ennek megfelelően néhány geográfus kulcsfontosságú szerepet játszott a nemzeti identitás alakításában. A harmadik szekcióban három ehhez kapcsolódó előadást hallottunk. Matteo Proto (Università di Bologna, Dipartimento di Storia 
Culture Civiltà) a már a békekonferenciát megelőzően is népszerű „egységes régió" elméletét és annak adaptációját ismertette. A koncepció alapján érvelt a két Marinelli (apa és fia) Olaszország politikai határainak az alpi vízválasztóhoz való igazítása mellett. Bottlik Zsolt (ELTE Regionális Tudományi Tanszék) és Demeter Gábor (MTA BTK Történettudományi Intézet) a balkáni geográfusok földrajzi és térképészeti munkáinak szerepét mutatták be. A különböző forrásból származó adatokból - akár hasonló módszerekkel - ellentétes üzenetű térképeket gyártottak a felek, ezzel támogatva nemzetalakítási céljaikat. Nicolas Ginsburger (Université de Paris X - Nanterre) a szerb geográfus Jovan Cvijić tevékenységét tanulmányozta. Ginsburger megállapításai szerint Cvijić sikerei azokban a személyi, tárgyi és intellektuális keringési folyamatokban rejlettek, melyek a vezető nyugati földrajztudósokhoz, valamint Párizshoz, a világháború végének földrajzi központjához kötötték. Ezek a folyamatok kulcsfontosságúak voltak a későbbi Jugoszlávia megszületésében, Cvijićet pedig a kor egyik kiemelkedő fontosságú geográfusává emelték. Noha a három kutatás eltérő módszerekkel közelítette meg a felvázolt problémákat, az előadások végén mégis hasonló következtetéseket hallhattunk: a világháború alatt és azt követően is kiemelt fontosságú volt a térség államaiban a stabil alapokon álló közös nemzeti identitás, illetve a földrajzi egység fontosságának hangsúlyozása, melyek segítségével a helyi geográfusok politikai célokat próbáltak legitimálni.

Az első nap utolsó szekciója arról a szerepről szólt, amelyet a földrajz a béketárgyalások után megerősödő nacionalizmusban töltött be. Norman Henniges (Leibniz-Institut für Länderkunde, Lipcse) Albrecht Penck 1925-ben elkészült térképének (Volks- und Kulturboden) keletkezését vizsgálta, mely a német területi revíziós céloknak biztosított tudományos támaszt. Az előadás rámutatott arra, hogy Penck munkájára a kortárs kulturális elméletek mellett a földrajzi kutatóutak tapasztalatai és a „bécsi iskola” természetföldrajzi közege is nagy hatással volt. Kathryn Ciancia (University of Wisconsin-Madison, Department of History) Volhínia két világháború közti viszontagságos helyzetét tárta fel. A történész felhívta a figyelmet a terület egységességének kérdésére, mely az aktuálpolitikai helyzetnek megfelelően változott: az 1920-as években Lengyelország az ukrán nemzetiségi tervek elfojtására a színes etnikai összetételű régió saját identitásának megerősítését támogatta, az 1930-as évekre azonban a lengyel nacionalizmus hevében belső határváltoztatásokkal és asszimilációt segítő intézkedésekkel próbálta eltüntetni ezeket a jegyeket.

Másnap reggel az ötödik szekcióban az előző nap utolsó témája folytatódott. Győri Róbert a két világháború közötti magyar revizionista tervekkel foglalkozott. Az előadás feltárta, hogy az Államtudományi Intézet munkássága és a magyar földrajztudomány általában hogyan járult hozzá a nemzeti tér és identitás gondolatának megerősítéséhez. Jankó Ferenc (Nyugat-Magyarországi Egyetem, Nemzetközi és Regionális Gazdaságtani Intézet) a burgenlandi identitás megalkotásának folyamatát mutatta be. Az osztrák és a német földrajz diskurzusainak és eredményeinek a korábban önálló régióként nem létező terület 
szerves egészként való értelmezésében, valamint az Ausztriához tartozás gondolatának megerősítésében játszott szerepét példákkal is szemléltette. Steven Jobbitt a magyar revizionista törekvések természeti érvelését vizsgálta. Az előadás rámutatott arra, hogy a Kárpátok vízválasztójának ideális határként való értelmezése nagy hatással volt a kor ökológiai szemléletére, a környezeti politika és a nemzeti identitásformálás különös kapcsolatát létrehozva. A kétszekciós téma a két világháború közötti revizionista földrajzi képzelet eltérő megközelítéseit mutatta be, sikeres és sikertelen példákat is nyújtva az új területek asszimilációjára, az elcsatolt területek visszaállítása melletti érvelésre és a nemzeti identitás alakítására.

A hatodik szekció a Feltámasztott nemzet eltemetése címet kapta, amely a két világháború között létrejövő államokban a második világháború utáni kommunista fordulatot fejezte ki. Timár Judit (MTA KRTK Regionális Kutatások Intézete) a nyugati marxista és a „vulgáris” magyar marxista földrajz kapcsolatáról és különbségeiről beszélt. Előadásában a két csoport eltérő kontextusát próbálta feltárni, összehasonlítva azok legjellemzőbb elemeit, folyóiratokban megjelenő narratíváit. Gyuris Ferenc a magyar földrajz második világháború utáni „szovjetizálását” mutatta be, melynek során az új kommunista rezsim a megöröklött népszerű, erős „régi” földrajzot ártalmasnak ítélte, és helyette egy új, a marxista-leninista filozófiának megfelelő földrajzi programot teremtett. Az előadás bemutatta ennek az új programnak a személyi, intézményi és tudományos változásait, emellett „remek” példával szolgált arra, hogy egy megszálló idegen ország központjából miként lehetséges egy „régi” tudományt egy másfajta „újjal” helyettesíteni. Bruno Schelhaastól (Leibniz-Institut für Länderkunde) egy ehhez nagyon hasonló témát hallhattunk. A szerző az NDK-beli akadémiai földrajz második világháborút követő fejlődését kutatta, ahol a magyar helyzethez hasonlóan a szovjetizáció elsődlegesen a régi földrajz leváltását jelentette. Az NDK-ban azonban a korábbi földrajzi elit - a „burzsoá földrajzosok” - alakították újra az akadémiai rendszert szovjet mintára. Az előadás megállapítása szerint a párhuzamosan fejlődő két német földrajz a hidegháború viszonyainak sajátos leképeződése volt.

A hetedik szekcióban tovább folytatódott a fenti téma: elsőként Czirfusz Márton (MTA KRTK Regionális Kutatások Intézete) beszélt a munkamegosztás szerepéről a nemzeti gondolat szocialista átalakításában. Az előadásból kiderült, hogy a szocialista gazdaságföldrajzosok számára a területi munkamegosztás a magyar nemzeti tér fontos építőeleme volt, ez a gondolat pedig számos nagy marxista gondolkodónál megjelent. Gyimesi Zoltán (ELTE Társadalom- és Gazdaságföldrajzi Tanszék) a „régi” földrajz egyik legjelentősebb alakjának, Mendöl Tibornak az ötvenes évek elején megírt, majd 1999-ben A földrajztudomány az ókortól napjainkig címmel kiadott munkájának történetét dolgozta fel. Az eredeti kézirat a nyelvezetben is visszaköszönő kettős narratívát használt, amely egyszerre tartalmazta a szerző saját elképzeléseit és az elvárásoknak megfelelő marxista-leninista szemléletmódot. Az újrakiadás azonban tudatosan 
különbözött az eredetitől, noha a szerkesztők ezt csak részben említették a bevezetőben. Gyimesi amellett érvelt, hogy a szöveg efféle elkendőzésével se a vitatott múlttal nem tudtak elszámolni, se Mendöl rehabilitálni kívánt munkásságát nem sikerült felszínre hozni. Az utóbbi két szekcióban hallott előadások aktuális témáknak számítanak, hiszen ezekkel a hagyományokkal korábban nem foglalkozott behatóan a történeti földrajz. A személyes és intézménytörténeti földrajzi jelenségek vizsgálatával ráadásul olyan, eddig szintén kevéssé kutatott elméleti kérdések is előtérbe kerülhetnek, mint a posztszocialista földrajz helye és szerepe a kortárs tudományban.

A nyolcadik, utolsó szekció kerekasztal-beszélgetése a földrajz kommunizmus utáni nemzetalakítási szerepének kérdését tárgyalta. Szó esett a politikai és a közösségi szerepekről, a posztszocialista (vagy épp posztkolonialista) traumákról, az azokat körülvevő mítoszokról és az ezekhez köthető felelősség kérdéséről is. A tudományos beszélgetés később kötetlenebb formában a Collegium kertjében rendezett esti bográcsozás alatt folytatódott. A baráti hangulatú eseményen emellett számos ambiciózus terv és ötlet merült fel, melyek jelezték a rendezvény sikerét. Másnap, július 13-án a konferencia előadóinak nagy része részt vett a szervezett buszos kiránduláson is, ahol - a vendégek többségének kívánságára - a „magyar puszta” egyes jellegzetességeit tekintettük meg. A konferencia programjában nem szerepelt ugyan, de ahhoz kapcsolódott Charles Withers július 15-én tartott földrajztudomány-történeti kutatószemináriuma. Az eseményt elsősorban az Eötvös József Collegium Mendöl műhelyének tagjai számára szervezték a Collegium kertjében.

Több hónappal a konferencia után számos tanulságot szűrhetünk le. Noha az eredeti tervekkel ellentétben a konferencia anyaga nem jelenik meg önálló kiadvány formájában, a lebonyolítás sikeresen zajlott. Nagy erőssége volt a rendezvénynek a geográfus és történész előadók nagy aránya, így a résztvevők eleve transzdiszciplináris keretben gondolkodtak, ez a fajta „korláttalanság” pedig az előadásokon is érződött. A neves külföldi kutatók részvétele - a személyes kapcsolati háló mellett - annak volt köszönhető, hogy egy korábban nem feldolgozott témában először adhattak elő tematikus konferencián, így az esemény remek találkozási lehetőséget is biztosított. Az itt megvitatott földrajzi kérdések nemcsak a geográfusok és történészek, hanem más tudományterületek képviselői számára is érdekesek lehetnek, hiszen összetett tartalmuk miatt sokféle megközelítésnek engednek teret. A tudományos eszmecsere sikerességét már az is bizonyította, hogy a szekciók végi beszélgetésekkor és azok folytatásán a szünetekben fontos kérdéseket vetett fel a hallgatóság, az ötletek a későbbi kutatások során bizonyulhatnak hasznosnak. A kétnapos konferencia a sürű program ellenére végig jól követhető volt, az eredetileg tervezett gondolati ív visszaköszönt az előadások fogadtatásában és a beszélgetések során is. A rendezvény egyetlen negatívumaként más posztszocialista országok képviselöinek hiányát említhetem, hiszen a magyar előadókon kívül csak az egykori NDK területéről érkező „delegáció” jelent meg. Ennek több oka is lehet (például a 
megfelelő kapcsolatok hiánya, a konferencia hírének korlátozott terjedése vagy az ottani földrajzi közegek hiányosságai), mindenesetre a jövőben mindenképpen érdemes lehet ezirányú kapcsolatokat is kiépíteni. Összességében a szervezők, az előadók és a hallgatóság véleménye szerint is sikeres volt a konferencia, számos értékes tapasztalattal gyarapodtunk és a pozitív visszajelzések alapján a jövőben is várható hasonló esemény. 